\title{
Exploratory Innovation, Exploitative Innovation, and Performance: Effects of Organizational Antecedents and Environmental Moderators
}

\author{
Justin J.P. Jansen, Frans A.J. Van den Bosch \\ and Henk W. Volberda
}

\begin{tabular}{|l|l|}
\hline \multicolumn{2}{|l|}{ ERIM REPORT SERIES RESEARCH IN MANAGEMENT } \\
\hline ERIM Report Series reference number & ERS-2006-038-STR \\
\hline Publication & July 2006 \\
\hline Number of pages & 32 \\
\hline Persistent paper URL & \\
\hline Email address corresponding author & jjansen@rsm.nl \\
\hline Address & Erasmus Research Institute of Management (ERIM) \\
& RSM Erasmus University / Erasmus School of Economics \\
& Erasmus Universiteit Rotterdam \\
& P.O.Box 1738 \\
& 3000 DR Rotterdam, The Netherlands \\
& Phone: $\quad+31104081182$ \\
& Fax: $\quad+31104089640$ \\
& Email: info@erim.eur.nl \\
& Internet: $\quad$ www.erim.eur.nl \\
\hline
\end{tabular}

Bibliographic data and classifications of all the ERIM reports are also available on the ERIM website: www.erim.eur.nl 


\section{ERASMUS RESEARCH INSTITUTE OF MANAGEMENT}

\section{REPORT SERIES \\ RESEARCH IN MANAGEMENT}

\begin{tabular}{|c|c|}
\hline \multicolumn{2}{|c|}{ ABSTRACT AND KEYWORDS } \\
\hline Abstract & $\begin{array}{l}\text { Research on exploration and exploitation is burgeoning, yet our understanding of the } \\
\text { antecedents and consequences of both activities remains rather unclear. We advance the } \\
\text { growing body of literature by focusing on the apparent differences of exploration and exploitation } \\
\text { and examining implications for using formal (i.e. centralization and formalization) and informal } \\
\text { (i.e. connectedness) coordination mechanisms. This study further examines how environmental } \\
\text { aspects (i.e. dynamism and competitiveness) moderate the effectiveness of exploratory and } \\
\text { exploitative innovation. Results indicate that centralization negatively affects exploratory } \\
\text { innovation while formalization positively influences exploitative innovation. Interestingly, } \\
\text { connectedness within units appears to be an important antecedent of both exploratory and } \\
\text { exploitative innovation. Furthermore, our findings reveal that pursuing exploratory innovation is } \\
\text { more effective in dynamic environments whereas pursuing exploitative innovation is more } \\
\text { beneficial to a unit's financial performance in more competitive environments. Through this richer } \\
\text { explanation and empirical assessment, we contribute to a greater clarity and better } \\
\text { understanding of how ambidextrous organizations coordinate the development of exploratory } \\
\text { and exploitative innovation in organizational units and successfully respond to multiple } \\
\text { environmental conditions. }\end{array}$ \\
\hline Free Keywords & Exploratory and Exploitative Innovation, Coordination Mechanisms, Environment, Performance \\
\hline Availability & $\begin{array}{l}\text { The ERIM Report Series is distributed through the following platforms: } \\
\text { Academic Repository at Erasmus University (DEAR), DEAR ERIM Series Portal } \\
\text { Social Science Research Network (SSRN), SSRN ERIM Series Webpage } \\
\text { Research Papers in Economics (REPEC), REPEC ERIM Series Webpage }\end{array}$ \\
\hline Classifications & $\begin{array}{l}\text { The electronic versions of the papers in the ERIM report Series contain bibliographic metadata } \\
\text { by the following classification systems: } \\
\text { Library of Congress Classification, (LCC) LCC Webpage } \\
\text { Journal of Economic Literature, (JEL), JEL Webpage } \\
\text { ACM Computing Classification System CCS Webpage } \\
\text { Inspec Classification scheme (ICS), ICS Webpage }\end{array}$ \\
\hline
\end{tabular}




\title{
EXPLORATORY INNOVATION, EXPLOITATIVE INNOVATION, AND PERFORMANCE: EFFECTS OF ORGANIZATIONAL ANTECEDENTS AND ENVIRONMENTAL MODERATORS
}

\author{
JUSTIN J.P. JANSEN*
}

FRANS A.J. VAN DEN BOSCH

HENK W. VOLBERDA

\author{
Department of Strategic Management and Business Environment \\ RSM Erasmus University \\ Erasmus University Rotterdam \\ P.O. Box 1738 \\ 3000 DR Rotterdam, The Netherlands \\ Tel: +31 (0)10 4089782 \\ Fax: +31 (0)104089013 \\ E-mail: jjansen@rsm.nl \\ www.strategyaterasmus.nl \\ www.erasmusinnovatiemonitor.nl/
}

Final version April 24, 2006

Accepted for Publication in

Management Science

* We would like to thank the departmental editor, John Boudreau, the associate editor, and two anonymous reviewers of Management Science for their valuable comments. Moreover, suggestions from Dania Dialdin, Ernst Verwaal, Raymond van Wijk, and Ed Zajac were helpful for improving earlier versions of this manuscript. We thank Ad Druijts for enabling data collection at the financial services firm. The Erasmus Research Institute of Management (ERIM) has supported this research 


\title{
EXPLORATORY INNOVATION, EXPLOITATIVE INNOVATION, AND PERFORMANCE: EFFECTS OF ORGANIZATIONAL ANTECEDENTS AND ENVIRONMENTAL MODERATORS
}

\begin{abstract}
Research on exploration and exploitation is burgeoning, yet our understanding of the antecedents and consequences of both activities remains rather unclear. We advance the growing body of literature by focusing on the apparent differences of exploration and exploitation and examining implications for using formal (i.e. centralization and formalization) and informal (i.e. connectedness) coordination mechanisms. This study further examines how environmental aspects (i.e. dynamism and competitiveness) moderate the effectiveness of exploratory and exploitative innovation. Results indicate that centralization negatively affects exploratory innovation while formalization positively influences exploitative innovation. Interestingly, connectedness within units appears to be an important antecedent of both exploratory and exploitative innovation. Furthermore, our findings reveal that pursuing exploratory innovation is more effective in dynamic environments whereas pursuing exploitative innovation is more beneficial to a unit's financial performance in more competitive environments. Through this richer explanation and empirical assessment, we contribute to a greater clarity and better understanding of how ambidextrous organizations coordinate the development of exploratory and exploitative innovation in organizational units and successfully respond to multiple environmental conditions.
\end{abstract}


As competition intensifies and the pace of change accelerates, firms need to renew themselves by both exploiting existing competencies and exploring new ones (Floyd and Lane 2000). The notion of exploration and exploitation (March 1991) has emerged as an underlying theme in research on organizational learning and strategy (Levinthal and March 1993, Vera and Crossan 2004), innovation (Danneels 2002, Lee et al. 2003, Rothaermel and Deeds 2004), and entrepreneurship (Shane and Venkataraman 2000). Various literatures have argued that organizations need to become ambidextrous (Gibson and Birkinshaw 2004, He and Wong 2004) and develop exploratory and exploitative innovation simultaneously in different organizational units (e.g. Benner and Tushman 2003, Tushman and O'Reilly 1996). Units that engage in exploratory innovation pursue new knowledge and develop new products and services for emerging customers or markets. Units pursuing exploitative innovation build upon existing knowledge and extend existing products and services for existing customers (Benner and Tushman 2003, p. 243). While the importance of pursuing both types of innovation has often been highlighted, much more remains to be understood how ambidextrous organizations coordinate the development of exploratory and exploitative innovation in organizational units.

First, there is little systematic evidence whether units adopt different coordination mechanisms to develop exploratory and exploitative innovation. Although previous research has asserted that organizational antecedents differentially influence exploratory and exploitative innovation (e.g. Benner and Tushman 2003, Hill and Rothaermel 2003), empirical studies examining such relationships with radical and incremental types of innovation produced mixed results (Cardinal 2001, Damanpour 1991, Ettlie et al. 1984, Dewar and Dutton 1986). Thus, it appears that the central tenet of units using diverse coordination mechanisms for exploratory and exploitative innovation remains unproven. The mixed findings may stem from the fact that previous studies have used the firm or business unit as unit of analysis, ignoring the fact that ambidextrous organizations might differentiate coordination mechanisms at the organizational unit-level. Moreover, prior research has tended to focus on formal hierarchical structure, thereby ignoring the increasing importance of informal social relations in coordinating the development of exploratory and exploitative innovation (Subramaniam and Youndt 2005). Cardinal (2001), for instance, argued that in addition to formal controls, informal social relations determine the extent to which exploratory and exploitative innovation can be developed. Yet, the impact of formal 
hierarchical structure and informal social relations on exploratory and exploitative innovation has not been studied in an integrated model. Focusing on organizational units, this study contributes to previous research through examining how formal and informal coordination mechanisms influence a unit's exploratory and exploitative innovation.

Second, a key characteristic of the strategic management discipline is its emphasis on a firm's competitive environment. Prior studies have found that the effectiveness of a strategic orientation (Hambrick 1983, Snow and Hrebiniak 1980), entrepreneurial orientation (Lumpkin and Dess 2001), or innovativeness (Zahra 1996, Zahra and Bogner 1999) depends on environmental aspects. Less welldocumented is the contingency perspective that underscores the effectiveness of a unit's exploratory and exploitative innovation under different contextual conditions. Levinthal and March (1993) and Lewin et al. (1999), for instance, posited that environmental aspects such as environmental dynamism and competitiveness moderate the relationship between both types of innovation and performance. Currently, there is little empirical evidence on the nature of this moderating effect and how it impacts a unit's financial performance. This study examines these effects and provides a fuller understanding how organizations may successfully respond to multiple environmental conditions through pursuing exploratory and exploitative innovations in organizational units. It suggests that both types of innovation may lead to diverse performance outcomes under different contextual conditions.

In summary, drawing from theories of organizational learning and strategic management, this study asserts that organizational units use different formal and informal coordination mechanisms to develop exploratory and exploitative innovations. We advance the growing body of literature on exploration and exploitation by focusing on their apparent differences and the implications for using coordination mechanisms. This study further suggests that the impact of exploratory and exploitative innovation on a unit's financial performance is moderated by environmental aspects. Through this richer explanation and empirical assessment, we contribute to a greater clarity and better understanding of how ambidextrous organizations coordinate the development of exploratory and exploitative innovation in organizational units and successfully respond to multiple environmental conditions. In the next section, we present the literature review and hypotheses. We examine the relationships between organizational antecedents, exploratory and exploitative innovation, environmental moderators, and financial 
performance. After describing our research method, we present the empirical findings using data on 283 organizational units from 115 autonomous branches of a large European financial services firm. We conclude with a discussion of the results, implications, and issues for further research.

\section{LITERATURE REVIEW AND HYPOTHESES}

\section{Exploratory and Exploitative Innovation}

Following previous literatures, we classify innovations along two domains: (1) the proximity to existing technologies, products, and services and (2) the proximity to existing customer/market segments (Abernathy and Clark 1985, Benner and Tushman 2003, Danneels 2002). Exploratory innovations are radical innovations and are designed to meet the needs of emerging customers or markets (Benner and Tushman 2003, p. 243, Danneels 2002). They offer new designs, create new markets, and develop new channels of distribution (Abernathy and Clark 1985). Exploratory innovations require new knowledge or departure from existing knowledge (Benner and Tushman 2002, Levinthal and March 1993, McGrath 2001). Conversely, exploitative innovations are incremental innovations and are designed to meet the needs of existing customers or markets (Benner and Tushman 2003, p. 243, Danneels 2002). They broaden existing knowledge and skills, improve established designs, expand existing products and services, and increase the efficiency of existing distribution channels (Abernathy and Clark 1985, p. 5). Hence, exploitative innovations build on existing knowledge and reinforce existing skills, processes, and structures (Abernathy and Clark 1985, Benner and Tushman 2002, Levinthal and March 1993, Lewin et al. 1999).

\section{Organizational Antecedents of Exploratory and Exploitative Innovation}

Organizational units use various coordination mechanisms to link and integrate different parts of their unit (Tushman and O’Reilly 1996, Van de Ven 1986). Coordination mechanisms direct attention and group together key resources and interdependent functions needed to develop innovations (Van de Ven 1986). However, they may differentially influence a unit's ability to pursue exploratory and exploitative innovation. Therefore, we examine two generic types of coordination mechanisms: (1) formal hierarchical structure and (2) informal social relations (cf. Ghoshal et al. 1994, Tsai 2002). 
Formal hierarchical structure. Formal hierarchical structure constitutes one of the most important ways of coordinating activities. We examine two main elements of a unit's hierarchical structure: centralization and formalization (e.g. Cardinal 2001, Lin and Germain 2003, Miller and Droge 1986, Zmud 1982). Centralization of decision-making reflects the locus of authority and decision-making (Damanpour 1991) and refers to the extent to which decision-making is concentrated in an organization (Aiken and Hage 1968). Centralization narrows communication channels (Cardinal 2001) and reduces the quality and quantity of ideas and knowledge retrieved for problem solving (Nord and Tucker 1987, Sheremata, 2000). In addition, it decreases the sense of control over work and diminishes the likelihood that unit members seek innovative and new solutions (Atuahene-Gima 2003, Damanpour 1991). Since exploratory innovation requires non-routine problem solving and deviation from existing knowledge, centralization of decision-making is likely to reduce exploratory innovation. Conversely, previous research has suggested that centralized authority is beneficial to speeding up exploitative innovation (Sheremata 2000). Exploitative innovation is limited in scope and newness, and generates less uncertainty about requisites for organizational units (Gopalakrishnan and Damanpour 1994). In this regard, effective decision-making processes for pursuing exploitative innovation tend to be narrowly channeled and more centralized (Cardinal 2001). Centralization of decision authority, therefore, increases information-processing efficiency and facilitates exploitative innovation.

Hypothesis 1. The higher a unit's centralization of decision-making, the (a) lower its level of exploratory innovation, and (b) higher its level of exploitative innovation

Formalization is the degree to which rules, procedures, instructions, and communications are formalized or written down (Khandwalla 1977). The reliance on rules and procedures hampers experimentation and ad hoc problem solving efforts (March and Simon 1958), and reduces the likelihood of individuals deviating from structured behavior (Weick 1979). Formalization acts as a frame of reference that constrains exploration efforts and directs attention toward restricted aspects of the external environment (Weick 1979). It hinders deviation from existing knowledge and a unit's variation seeking behavior. Accordingly, formalization constrains exploratory innovations. Rather, formalization is generally established in order to respond to environmental phenomena in a known way 
(Daft and Lengel 1986, Lyles and Schwenk 1992). Formalization is aimed at reducing variance through incremental improvements in processes and outputs (Benner and Tushman 2003). Zollo and Winter (2002), for instance, argue that formalization facilitates the generation of proposals to improve existing routines. Once changed, these improved routines become standardized activities that will be performed for existing sets of customers (Benner and Tushman 2003). Through formalization units codify best practices so as to make them more efficient to exploit, easier to apply, and accelerate their implementation (Zander and Kogut 1995). Thus, formalization enhances exploitative innovations through improvement of current products, services, and processes.

Hypothesis 2. The higher a unit's formalization, the (a) lower its level of exploratory innovation, and (b) higher its level of exploitative innovation

Informal social relations. Informal social relations concern personal linkages between people and comprise a more voluntary mode of coordination than hierarchical structure (Tsai 2002). Although previous research has shown that interfirm or interunit relations affect knowledge transfer and learning (Dhanaraj et al. 2004, Hansen 2002, Uzzi and Lancaster 2003), the impact of social relations among individuals within units on exploratory and exploitative innovation remains unclear. Therefore, our study examines the structural dimension of social relations, which concerns the overall pattern of a unit's social network in terms of density, or connectedness (Nahapiet and Ghoshal 1998, Sheremata 2000, Tsai and Ghoshal 1998, Uzzi 1997).

Connectedness increases opportunities for informal hall talk and accessibility to knowledge sources within organizational units (Jaworksi and Kohli 1993). It helps combining knowledge among a range of individuals and developing new knowledge underlying exploratory innovation (Atuahene-Gima 2003, McFadyen and Cannella 2004). In addition, Subramaniam and Youndt (2005) argued that social relations assist in establishing legitimacy and in enabling adoption of exploratory innovation. Beyond a moderate level, however, the density of social networks may limit access to divergent perspectives and to alternative ways of doing things (Nahapiet and Ghoshal 1998, p. 245). As highly-dense networks diffuse strong norms and establish shared behavioral expectations, they reduce deviant behavior, limit search scope, and selective perception of alternatives (Rowley et al. 2000, Uzzi, 1997). Dense social 
relations among unit members, therefore, will eventually constrain departure from existing knowledge and decrease a unit's exploratory innovation. Accordingly, we expect an inverted U-shaped relationship between connectedness and exploratory innovation. To pursue exploitative innovation, on the other hand, organizational units need to efficiently draw upon and refine prevailing knowledge (Subramaniam and Youndt 2005). Connectedness is advantageous for developing trust and cooperation among unit members (Adler and Kwon 2000, Walker et al. 1997). It permits individuals to develop a deep understanding in order to further refine and improve existing products, processes, and markets (Rowley et al. 2000). Moreover, dense social relations enable unit members to share experiences with regard to how to implement certain improvements (Dyer and Nobeoka 2000). Connectedness within organizational units, therefore, facilitates improving existing knowledge resources and increases a unit's exploitative innovation.

Hypothesis 3a. There will be an inverted U-shaped relationship between a unit's connectedness among its members and the level of exploratory innovation Hypothesis $3 b$. The higher a unit's connectedness among its members, the higher its level of exploitative innovation

\section{The Moderating Role of External Environment on the Effectiveness of Exploratory and}

\section{Exploitative Innovations}

The impact of the external environment on innovativeness and performance has been widely acknowledged (e.g. Zahra 1996, Zahra and Bogner 1999). Miller and Friesen (1983), for instance, found that environmental aspects moderate the relationship between innovation and performance. Regarding exploratory and exploitative innovations, previous literatures argued that environmental dynamism and competitiveness are likely to moderate the impact of both types of innovations on performance (Levinthal and March 1993, Lewin et al. 1999).

Environmental dynamism refers to the rate of change and the degree of instability of the environment (Dess and Beard 1984). Previous research not only reflects environmental dynamism through the amount of change, but also through the unpredictability of change (cf. Dess and Beard 1984). Dynamic environments may be characterized by changes in technologies, variations in customer 
preferences, and fluctuations in product demand or supply of materials. Dynamic environments make current products and services obsolete and require new ones to be developed (Jansen et al. 2005, Sorensen and Stuart 2000). To minimize this threat of obsolescence, organizational units need to introduce exploratory innovations that depart from existing products, service, and markets.

Organizational units that pursue such innovations can capitalize on changing circumstances by creating new products and services or meeting the needs of emerging markets (Zahra 1996). They create opportunities for above-normal return by targeting premium market segments (Levinthal and March 1993, Zahra and Bogner 1999) and creating new niches (Lumpkin and Dess 2001). Hence, in dynamic environments, we expect organizational units pursuing exploratory innovations to increase their financial performance. Conversely, organizational units pursuing exploitative innovations are likely to decrease their performance. Such organizational units are inclined to exploit existing products, services, and markets. They are likely to fall behind because they become consistently better at performing routines that are less and less valued by the environment (Sorenson and Stuart 2000). Accordingly, Hypothesis 4. Environmental dynamism (a) positively moderates the relationship between exploratory innovation and financial performance, and (b) negatively moderates the relationship between exploitative innovation and financial performance

Environmental competitiveness is the extent to which external environments are characterized by intense competition (Matusik and Hill 1998). It refers to the degree of competition reflected in the number of competitors and the number of areas in which there is competition (Miller 1987). Competitive environments have been associated with intensive pressures for higher efficiency and lower prices (Matusik and Hill 1998) that lead to tighter margins and less organizational slack (Zahra 1996). Miller and Friesen (1983, p. 223) argued that extensive risk taking, forceful proactiveness, and strong emphasis on novelty (i.e. exploratory innovation) can be hazardous when competitive conditions are becoming more demanding. Outcomes of exploratory innovations tend to rapidly become diffused over the population of competitors (Levinthal and March 1993). Moreover, environmental competitiveness usually reduces available resources for exploratory innovations (Miller and Friesen 1983, Zahra 1996) and pursuing such high-risk and high-cost innovations would considerably harm the 
viability of organizational units (Zahra and Bogner 1999). We therefore propose that environmental competitiveness negatively moderates the effectiveness of exploratory innovations. Conversely, organizational units reacting to existing trends and demands through modifying or expanding current products, services, and markets (i.e. exploitative innovation) are likely to enhance their performance in competitive environments (Lumpkin and Dess 2001). They pursue exploitative innovations in order to better cater for existing customers and build customer loyalty without substantial costs associated with exploratory innovations. Through increased advertising and enhanced tailoring of existing products and services (Miller 1987), these organizational units try to charge a premium and capture additional market share (Zahra and Bogner 1999). Accordingly, organizational units pursuing exploitative innovation in competitive environments are likely to increase their financial performance.

Hypothesis 5. Environmental competitiveness (a) negatively moderates the relationship between exploratory innovation and financial performance, and (b) positively moderates the relationship between exploitative innovation and financial performance

\section{METHOD}

\section{Setting and Data Collection}

The empirical research was conducted at a large European financial services firm. The financial services sector is an interesting case for innovation researchers since it has been confronted with the blurring of industry boundaries and with new entrants from, among others, the retail- and telecom industry (Flier et al. 2003). These changes have triggered incumbent financial services firms to pursue several exploratory and exploitative innovations, such as the introduction of ATM's, Internet banking, and Mobile banking (Han et al. 1998, Pennings and Harianto 1992). The firm has total assets of more than $\$ 350$ billion and ranks among the top 30 on the Fortune Global 500 in terms of total revenue in the banking industry. It is a broad-based financial service provider having branches in various countries. These branches are geographically distinct, autonomous decision entities with their own board of directors. They have autonomy with respect to types of products and services offered and markets within which to provide these products and services. Organizational units in these branches provide products and services that cover asset management, mortgages, loans and savings, insurance, leasing, equity participation, corporate banking, and investment banking. Each organizational unit has 
its own management team with budget responsibilities regarding several aspects of their operations such as pursuing exploratory and exploitative innovation. Moreover, organizational units within branches operate in markets with varying levels of environmental dynamism and competitiveness - a condition required to observe units pursuing different innovative activities (Han et al. 1998).

To deal with potential problems associated with single-informant bias and common method bias, we temporarily separated the measurement of independent and dependent variables and collected data at two different points in time. In 2002, a survey assessing centralization, formalization, and connectedness was administered to the general manager of 769 organizational units within 220 branches in one country. To ensure confidentiality, we agreed not to reveal the name of the manager and asked to return the questionnaire directly to the research team. Unit managers from 462 organizational units returned their questionnaire, representing a response rate of 60 percent. In 2003 , approximately ten months after the first survey, a second survey was mailed to the same 462 organizational unit managers to assess their unit's exploratory innovation, exploitative innovation, environmental dynamism and competitiveness. We received 283 surveys from organizational units in 115 branches, representing a final response rate of 36.8 percent. The respondents of these 283 organizational units had a mean company tenure of 7.85 years $($ s.d. $=8.24)$. The average size of the organizational units was 33.37 (s.d. $=20.79)$ full-time employees.

To test for nonresponse bias, we examined differences between respondents and nonrespondents for our final sample. T-tests showed no significant differences based on the number of full-time employees of organizational units and their associated branches, total assets of branches, and units' prior performance. We also compared early and late respondents in terms of demographic characteristics and model variables. These comparisons did not reveal any significant differences $(\mathrm{p}<.05)$, indicating that nonresponse bias was not a problem.

To examine reliability issues associated with single-informant data, we surveyed two additional members of the 283 responding organizational units in 2003. Both management team members and senior employees of organizational units were asked to participate and to assess their unit's exploratory innovation, exploitative innovation, environmental dynamism, and environmental competitiveness. This follow-up survey resulted in 79 responses from 56 organizational units, or $19.8 \%$ of the organizational 
units from the final sample, that were comparable in size, age, and prior performance to our final sample. We calculated an interrater agreement score $\left(\mathrm{r}_{\mathrm{wg}}\right)$ for data on these variables (James et al. 1993). The median interrater agreements were $.74, .78, .91$, and .89 , respectively for exploratory innovation, exploitative innovation, environmental dynamism, and environmental competitiveness, suggesting adequate agreement. Intra-class correlations revealed a strong level of interrater reliability: correlations were consistently significant at the .001 levels (Jones et al. 1983).

\section{Measurement and Validation of Constructs}

This study used existing scales from the literature, however, appropriate scales for exploratory and exploitative innovation were not available. Therefore, the authors reviewed relevant literature and generated a pool of items to tap the domain of each construct. Next, to enhance the construct validity of the survey measures, we conducted a pretest involving in-depth pilot interviews with 15 managers with various tenures at different branches. The managers were asked to complete the questionnaire and indicate any ambiguity regarding the phrasing of the items. During follow-up interviews, managers were invited to provide suggestions for improvement of the questionnaire. After this pretest, the phrasing of items was further enhanced by the authors and peers and resulted in the final version. The appendix provides all items of study variables.

Dependent variables. Financial performance of organizational units was measured through internal corporate records by a unit's average profitability from 2003 up to one year after the measurement of exploratory and exploitative innovation. Because organizational units may have different strategic priorities, we adjusted financial performance data to evaluate each organizational unit. Following Tsai (2001), we used a unit's profitability-achieved rate, namely a unit's profitability divided by its target profitability. We ascertained a unit's profitability as well as target profitability through internal corporate records. We averaged the profitability-achieved rate over a one-year period to help guard against random fluctuations in the data.

To develop measures for exploratory and exploitative innovation, we generated items on a sevenpoint scale by carefully examining existing literature (Abernathy and Clark 1985, Benner and Tushman 
2003, Lewin et al. 1999, March 1991, Uzzi and Lancaster 2003) and analyzing interviews with managers at branches of the financial services firm. The resulting six-item measure for exploratory innovation $(\alpha=.86)$ captured the extent to which units depart from existing knowledge and pursue innovations for emerging customers or markets. In the context of financial services, exploratory innovation is related to developing new products and services not previously provided by organizational units such as fundamentally new loan structures and contingent contracts (Uzzi and Lancaster 2003). The measure for exploitative innovation $(\alpha=.80)$ captured the extent to which units build upon existing knowledge and meet the needs of existing customers (Abernathy and Clark 1985, Benner and Tushman 2003, Danneels 2002). Prior research on financial services has related exploitative innovation to aggressive lending, shopping the market and increasing efficiency (e.g. Uzzi and Lancaster 2003). To further examine reliability and ensure validity of our measures for exploratory and exploitative innovation, we measured both types of innovation at the branch level through surveying managing directors from our sample of branches in 2003. A total of 110 questionnaires were completed and returned. First, alpha reliabilities of exploratory and exploitative innovations in the sample of managing directors were .86 and .77 respectively, revealing strong reliability of both measures. Second, we conducted exploratory factor analysis of the 12 items pertaining to exploratory and exploitative innovation. Results revealed a two-factor solution with significant factor loadings above .58 and crossloadings below .29 , indicating convergent and discriminant validity of both measures in the sample of managing directors. Third, correlations between exploratory and exploitative innovation at the branchlevel and the average level of both types of innovations among organizational units within the same branch were positive and significant $(\mathrm{p}<.01)$. These findings provided strong support for the reliability and validity of our two measurements for exploratory and exploitative innovation.

Independent and moderating variables. We used the sub-construct of hierarchy of authority (Hage and Aiken 1967) to measure centralization of decision-making ( $\alpha=.71)$. As Dewar et al. (1980) indicate, the scale is found to be both reliable and valid. To measure formalization, we used a five-item formalization scale ( $\alpha=.74)$ from Desphandé and Zaltman (1982). Connectedness ( $\alpha=.78)$ was measured with a five-item scale adapted from Jaworski and Kohli (1993). They developed a scale for 
connectedness that measured the extent to which employees were networked to various levels of the hierarchy in their organizational unit. Based on previous literatures, a five-item measure was included that captured environmental dynamism (cf. Dill 1958, Volberda and Van Bruggen 1997). The scale for environmental dynamism $(\alpha=.87)$ tapped into the rate of change and the instability of the external environment. A four-item scale was used for environmental competitiveness $(\alpha=.86)$ that measured the extent to which a unit's external environment is characterized by intense competition that is reflected in the number of competitors and the number of areas in which there is competition (Birkinshaw et al. 1998, Jaworski and Kohli 1993).

We assessed the construct validity of all items pertaining to our constructs through exploratory and confirmatory factor analysis. Exploratory factor analysis of all items (dependent variables, independent variables, and moderating variables) clearly replicated the intended 7-factor structure. Each item loaded clearly on their intended factor (all factor loadings were above .61 with cross-loadings below .34) and all factors had eigenvalues greater than 1, supporting the 7-factor solution. An integrated CFA on all items (with each item constrained to load only on the factor for which it was the proposed indicator) yielded a model that fits the data well $\left(\chi^{2} / \mathrm{df}=2.20\right.$, goodness-of-fit index $[\mathrm{GFI}]=.92$ comparative fit index $[\mathrm{CFI}]=.91$, root-mean-square error of approximation $[\mathrm{RMSEA}]=.056)$. Item loadings were as proposed and significant $(\mathrm{p}<.01)$. To examine discriminant validity, we also assessed two-factor models for each pair. Constraining each correlation in the second model to unity and examining the difference in chi-square values, we found significant test statistics $(\mathrm{p}<.001)$ for each pair. Accordingly, the measurements used in our study are not only theoretically, but also empirically distinguishable.

Control variables. In the empirical study, we controlled for possible confounding effects by including various relevant control variables. As larger units may have more resources, yet may lack the flexibility to explore, we included the natural logarithm of the number of full-time employees within units to account for unit size. Organizational units situated in large branches may also have access to available branch resources that can be used to develop exploratory and exploitative innovation (Gooding and Wagner 1985). Accordingly, we included branch size as the natural logarithm of the number of fulltime employees within a branch. A unit's age, measured by the number of years from its founding, was 
also included. Previous studies have shown that older units may have increased cumulative experience that enhances innovation; however, they may also encounter problems in keeping abreast with external developments (Sorensen and Stuart 2000). The number of functional areas represented in a unit is beneficial to considering a greater range of perspectives and to facilitating creativity (Milliken and Martins 1996, Moorman and Miner 1997). Yet, functional diversity may create difficulties in resolving differences among perspectives and slow down exploitative innovation. We therefore controlled for functional diversity measured as the number of functional areas represented in organizational units (e.g. Sethi et al. 2001). To control for the effect that units may specialize in different markets and have different ranges of products and services, we included unit client focus that indicates whether the unit provided products and services for private clients (coded as 0 ) or for business clients (coded as 1). Organizational units with a strong history of high performance are likely to invest in innovation. Hence, we included a unit's past performance measurements. Because units may have different strategic priorities, we adjusted performance data to evaluate each unit. Following Tsai (2001), we used a unit's profitability-achieved rate, a unit's profitability divided by its target profitability. We also controlled for branch's past performance and included a branch's profitability-achieved rate, a branch's return on investment divided by its target return. The past performance measurements as well as the achieved rates for the units and branches in this study were ascertained for the time period 2000-2002 through internal corporate records.

\section{ANALYSIS AND RESULTS}

Table 1 presents descriptive statistics and correlations for the study variables. Table 2 presents the results of the hierarchical regression analyses for exploratory innovation, exploitative innovation, and financial performance. Prior to the creation of the interaction terms in model 6, we mean centered the independent variables to reduce multicollinearity (Aiken and West 1991). Moreover, to examine multicollinearity, we calculated variance inflation factors (VIF) for each of the regression equations. The maximum VIF within the models was 1.44, which is well below the rule-of-thumb cut-off of 10 (Neter et al. 1990).

Insert Table $1 \& 2$ about here 
The baseline models (models 1, 3, and 5) contain control variables. Models 2 and 4 introduce organizational antecedents of a unit's exploratory and exploitative innovation and model 6 examines moderating effects of environmental dynamism and competitiveness on a unit's financial performance.

Regarding the effects of centralization of decision-making on exploratory and exploitative innovation, model 2 shows that the coefficient for exploratory innovation is negative and significant ( $\beta$ $=-0.17, \mathrm{p}<.01)$. Hypothesis $1 \mathrm{a}$ is supported. Model 4 shows that the coefficient for exploitative innovation is positive but not significant $(\beta=0.04$, ns), thus not supporting hypothesis $1 \mathrm{~b}$. Although centralization decreases the ability of organizational units to pursue exploratory innovation, it does not support a unit's exploitative innovations as predicted. Regarding formalization, results in model 2 show that formalization does not decrease a unit's exploratory innovation. Although the coefficient is negative, it is not significant $(\beta=-0.07, \mathrm{~ns})$, thereby not supporting hypothesis $2 \mathrm{a}$. Hypothesis $2 \mathrm{~b}$ that proposed a positive relationship between formalization and a unit's exploitative innovation is supported $(\beta=0.18, \mathrm{p}<.01)$. Thus, our findings indicate that formalization enhances a unit's ability to pursue exploitative innovation. Regarding social relations in organizational units, we predicted an inverted Ushaped relationship between connectedness and exploratory innovation. As shown in model 2, the coefficient for connectedness is positive and significant $(\beta=0.20, \mathrm{p}<.01)$, however, the coefficient for the squared term is negative and not significant $(\beta=-0.08, \mathrm{p}>.10)$. Accordingly, the relationship between connectedness and exploratory innovation is positive rather than curvilinear, thereby not supporting hypothesis 3a. As shown in model 4, the coefficient for connectedness and exploitative innovation is positive and significant $(\beta=0.21, \mathrm{p}<.01)$, supporting hypothesis $3 \mathrm{~b}$. Overall, these findings suggest that densely connected social relations within organizational units positively influence the ability to develop exploratory innovation as well as exploitative innovation.

Regarding the moderating effect of environmental dynamism, model 6 shows that the interaction between exploratory innovation and environmental dynamism is positive and significant $(\beta=0.15, \mathrm{p}<$ $.01)$. Hypothesis $4 \mathrm{a}$ is supported. To plot this interaction, exploratory innovation and environmental dynamism took the values of one standard deviation below (i.e. low level) and above (i.e. high level) the mean. The plot of the interaction is shown in Figure 1. Consistent with hypothesis 4a, Figure 1 
shows a positive relationship between exploratory innovation and financial performance when environmental dynamism is high. Moreover, it also reveals that organizational units pursuing exploratory innovation in stable environments (i.e. low level of environmental dynamism) decrease their financial performance. As shown in model 6, the coefficient for the interaction between exploitative innovation and environmental dynamism is negative and significant $(\beta=-0.23, \mathrm{p}<.001)$ as proposed by hypothesis $4 \mathrm{~b}$. Consistently, the plot of this interaction in Figure 2 shows a negative relationship between exploitative innovation and financial performance when environmental dynamism is high. Moreover, this figure also suggests that the more organizational units pursue exploitative innovation in stable environments (i.e. low level of environmental dynamism), the more they increase their financial performance.

As shown in model 6, the interaction between exploratory innovation and environmental competitiveness does not decrease financial performance $(\beta=-0.05, p>.10)$. Although the coefficient is negative, it is not significant, thus hypothesis $5 \mathrm{a}$ is not supported. As predicted by hypothesis $5 \mathrm{~b}$, the interaction effect between exploitative innovation and environmental competitiveness is positive and significant $(\beta=0.19, \mathrm{p}<.001)$. Thus, as plotted in Figure 3, organizational units pursuing exploitative innovation in highly competitive environments increase their financial performance.

\section{DISCUSSION AND CONCLUSION}

Research on exploration and exploitation is burgeoning, yet our understanding of the antecedents and consequences of both activities remains rather unclear. Although prior research has suggested that organizational antecedents differentially affect exploratory and exploitative innovations, empirical examinations have produced mixed results. Moreover, empirical studies have only started exploring the moderating role of the external environment on the effectiveness of exploratory and exploitative innovation. Focusing on organizational units, the objective of this study was to explore how organizations coordinate the development of exploratory and exploitative innovation in organizational units and successfully respond to multiple environmental conditions.

Our study underscores previous conceptual assertions that formal hierarchal structure, i.e. centralization and formalization, differentially influences exploratory and exploitative innovation (e.g. Benner and Tushman 2003). Centralization has been studied widely in innovation literatures and 
supposed to negatively influence innovativeness (e.g. Damanpour 1991), however, the relationship between centralization of decision-making and different types of innovation remains rather unclear (Cardinal 2001, Damanpour 1991, Dewar and Dutton 1986). Our findings demonstrate that centralization negatively influences a unit's exploratory innovation. Accordingly, it reduces non-routine problem-solving and the likelihood that unit members seek innovative and new exploratory solutions (Atuahene-Gima 2003). Although centralization negatively influences exploratory innovation, it does not support exploitative innovation as predicted. Whereas Cardinal's (2001) research in the pharmaceutical industry revealed that centralization facilitated drug enhancement through exploitation of knowledge sources, our study found no support for such a hypothesized positive effect of centralization. A possible explanation for the insignificant relationship between centralization and exploitative innovation could be that in our research context, the financial services industry, decentralization of decision authority may be required to execute tasks and initiate ideas for improving existing products and services or enhancing customer service quality (Kirkman and Rosen 1999). To fully understand this relationship, future research may examine whether additional characteristics of innovations activities, such as uncertainty (Cardinal 2001), vary across industries and moderate the relationship between centralization and exploitative innovation.

With regard to formalization, we found a positive relationship between the extent of rules and procedures within organizational units and exploitative innovation. This observation reinforces the notion that rules and procedures are established to incrementally improve processes and outputs (Benner and Tushman 2003, Daft and Lengel 1986). Formalization makes existing knowledge and skills explicit and accelerates the diffusion of best practices within units (Zander and Kogut 1995). Regarding exploratory innovation, our findings did not provide support for the predicted negative effect of formalization on a unit's exploratory innovation. In this way, our study bears similarities with recent insights that rules and procedures might not be as detrimental to exploration efforts as previously assumed. Adler and Borys (1996), for instance, argued that well-designed rules and procedures enable employees to better master their tasks and functions. Moreover, codification efforts of newly developed knowledge in written rules and procedures might help units to facilitate the replication and diffusion of an exploratory innovation (Zollo and Winter 2002). In this sense, formalization does not simply 
produce inertial forces and a focus towards exploitation (e.g. Cardinal 2001), however, its effect is contingent upon its design and its ability to produce an enabling rather than a coercive bureaucracy (Adler and Borys 1996).

Our findings reveal that dense social relations within units are an effective coordination mechanism that yields multiple benefits. First, connectedness shows a significant positive effect on both exploratory and exploitative innovation. These results highlight the importance of social relations manifested in organizational units to pursue both exploratory and exploitative innovation. Subramanian and Youndt (2005), for instance, found that a firm's social capital enables its capability to develop incremental and radical innovations. Our results suggest that managers may develop densely connected social relations within their units to increase a unit's contextual ambidexterity, i.e. its ability to simultaneously pursue both types of innovations (Gibson and Birkinshaw 2004). Second, a comparison of the full model with restricted models containing either formal or informal coordination mechanisms (cf. Hansen and Wernerfelt 1989, Kota and Nair 1995) also shows that informal coordination mechanisms (i.e. connectedness) are more important than formal coordination mechanisms (centralization and formalization) in predicting both types of innovation. Accordingly, our study indicates that informal coordination mechanisms not only contribute to pursuing both exploratory and exploitative innovation, but are also more important than formal coordination mechanisms for developing either exploratory or exploitative innovation.

Prior research has argued that the nature of the external environment has an important role in the effectiveness of types of innovation (Zahra 1996, Zahra and Bogner 1999). Our findings provide substantial support for such environmental moderators. They provide various managerial implications regarding how organizational units successfully cope with various pressures from external environments. Specifically, results suggest that organizational units operating in more dynamic environments increase their financial performance by pursuing exploratory innovations. They resist the threat of obsolescence of their competences not only by developing new products and services (e.g. Zahra and Bogner 1999), but also by entering new markets and finding new customers. On the other hand, efforts of organizational units to respond to environmental changes through exploitation of existing products, services, and markets appear to have a negative effect on financial performance. 
These organizational units fall behind as they try to improve and extend existing products and services for markets that are in decline (Leonard-Barton 1992, Levinthal and March 1993, Sorensen and Stuart 2000). Hence, the empirical findings contribute to previous literatures by revealing that environmental dynamism differentially moderates the effectiveness of exploratory and exploitative innovations.

Contrary to our prediction, pursuing exploratory innovations in competitive environments do not significantly decrease their financial performance. Although exploratory innovations decrease a unit's slack (Zahra 1996), they may establish new ways of generating above-normal returns. A possible explanation for the deviant finding could be that duration of environmental competitiveness plays a role. During long-term competitive rivalry, for instance, organizational units may find themselves trapped in endless improvement of existing products, services, and processes (Levinthal and March 1993). The only way to refrain from decreasing margins may be developing radically new products and services for emerging markets or customers. Thus, although on average pursuing exploratory innovations might be detrimental during short periods of competitive rivalry it may be the only way to establish new markets during long periods of competitive rivalry (Levinthal and March 1993). To further investigate the moderating role of environmental competitiveness, future research should include a measurement of the duration of environmental competitiveness. As predicted, empirical results show that organizational units pursuing exploitative innovations in highly-competitive environments improve their performance. Hence, units are able to successfully operate in highlycompetitive environments by expanding current products and services and defending existing markets through increasing customer loyalty.

\section{Limitations and future research directions}

Various limitations, which provide meaningful directions for future research, merit discussion. First, although the collection of performance data through internal corporate records and the temporary separation of the independent and dependent measures provide valuable methodological contributions, the issues of common method bias and unobserved heterogeneity cannot be totally ruled out. However, the inclusion of several relevant control variables, Harman's one-factor analysis, and the differential effects of study variables found on both types of innovation reduced our concerns. Nevertheless, future research may consider a longitudinal research design to better assess how organizational antecedents 
affect exploratory and exploitative innovation over time. Second, new scales for exploratory and exploitative innovation were developed. Although we conducted several additional analyses to assess the validity of these measurements, it would be useful to measure both types of innovation using complementary measurements and relate these to our measurements. Future research may also provide a more detailed examination of organizational antecedents as well as outcomes of new-to-unit vs. newto-market innovations. Third, since our study focuses on the structural dimension of social networks, future research may examine the impact of the relational dimension of social networks. Relational embeddedness, or the strength of social relations between unit members, has been shown to increase the exchange of knowledge (Dhanaraj et al. 2004, Hansen 2002), which might impact the ability of units to pursue exploratory and exploitative innovation. Fourth, our survey research was conducted at multiple organizational units in autonomous branches of a large financial services firm. Our focus helped to control for corporate-, industry- and country-specific differences that might have otherwise masked significant effects. Empirical studies in a wider variety of organizations within non-service industries are necessary to generalize the findings further. Fifth, our empirical study included performance data up to one year after the measurement of exploratory and exploitative innovations. Future studies may benefit from gathering performance data that span more than one year. Moreover, it would enable analyzing performance implications at different points in time to contrast the effects of exploratory and exploitative innovation. Future studies may also examine other dimensions of a unit's performance, such as sales growth, and market share. Sixth, although our study provides new insights into organizational antecedents and consequences of exploratory and exploitative innovation, it does not address how unit managers are triggered to change levels of exploratory and exploitative innovation. It would be useful to conduct in-depth studies to better understand how change efforts initiate.

All in all, our study highlights various theoretical and managerial implications through providing new insights into levers for increasing levels of exploratory and exploitative innovations. In response to the plea for developing and synchronizing both types of innovations, our study not only examines how ambidextrous organizations might successfully coordinate exploratory and exploitative innovation in organizational units but also reveals under which environmental conditions both are effective. 


\section{REFERENCES}

Abernathy, W.J., K. Clark 1985. Mapping the Winds of Creative Destruction. Research Policy 14 3-22

Adler, P.S., B. Borys. 1996. Two Types of Bureaucracy: Enabling and Coercive. Administrative Science Quarterly 41 61-89

Adler, P.S., S. Kwon. 2002. Social Capital: Prospects for a New Concept. Academy of Management Review 27 17-40

Aiken, M., J. Hage. 1968. Organizational Interdependence and Intraorganizational Structure. American Sociological Review 33 912-930

Aiken, L.S., S.G. West. 1991. Multiple Regression: Testing and interpreting interactions. Sage Publishing, Thousand Oaks

Atuahene-Gima, K. 2003. The Effects of Centrifugal and Centripetal Forces on Product Development Speed and Quality: How does Problem Solving Matter? Academy of Management Journal 46 359374

Benner, M.J., M.L. Tushman. 2002. Process Management and Technological Innovation: A Longitudinal Study of the Photography and Paint Industries. Administrative Science Quarterly 47 676-706

Benner, M.J., M.L. Tushman. 2003. Exploitation, Exploration, and Process Management: The Productivity Dilemma Revisited. Academy of Management Review 28 238-256

Birkinshaw, J., N. Hood, S. Jonsson. 1998. Building Firm-specific Advantages in Multinational Corporations: The Role of Subsidiary Initiative. Strategic Management Journal 19 221-241

Cardinal, L.B. 2001. Technological Innovation in the Pharmaceutical Industry: The Use of Organizational Control in Managing Research and Development. Organization Science 12 19-36

Daft, R.L., R.H. Lengel. 1986. Organizational Information Requirements, Media Richness and Structural Design. Management Science 32 554-571

Damanpour, F. 1991. Organizational Innovation: A Meta-Analysis of Effects of Determinants and Moderators. Academy of Management Journal 34 555-590

Danneels, E. 2002. The Dynamics of Product Innovation and Firm Competences. Strategic Management Journal 23 1095-1121 
Desphande, R., G. Zaltman. 1982. Factors affecting the use of Market Research Information: A Path Analysis. Journal of Marketing Research 19 14-31

Dess, G.G., D.W. Beard. 1984. Dimensions of Organizational Task Environments. Administrative Science Quarterly 29 52-73

Dewar, R.D., J.E. Dutton. 1986. The Adoption of Radical and Incremental Innovations: An Empirical Analysis. Management Science 32 1422-1433

Dewar, R.D., D.A. Whetten, D. Boje. 1980. An Examination of the Reliability and Validity of the Aiken and Hage Scales of Centralization, Formalization, and Task Routiness. Administrative Science Quarterly 25 120-128

Dhanaraj, C., M.A. Lyles, H.K. Steensma, L. Tihanyi. 2004. Managing tacit and explicit knowledge transfer in IJVs: the role of relational embeddedness and the impact on performance. Journal of International Business Studies 35 428-442

Dill, W.R. 1958. Environments as an Influence on Managerial Autonomy. Administrative Science Quarterly 2 409-443

Dyer, J.H., K. Nobeoka 2000. Creating and managing a high-performance knowledge-sharing network: the Toyota case. Strategic Management Journal 21 345-367

Ettlie, J.E., W.P. Bridges, R.D. O’Keefe. 1984. Organization Strategy and Structural Differences for Radical versus Incremental Innovation. Management Science 30 682-695

Flier, B., F.A.J. Van den Bosch, H.W. Volberda. 2003. Coevolution in Strategic Renewal Behaviour of British, Dutch, and French Financial Incumbents: Interaction of Environmental Selection, Institutional Effects, and Managerial Intentionality. Journal of Management Studies 40 2163-2187

Floyd, S.W., P.J. Lane. 2000. Strategizing Throughout the Organization: Managing Role Conflict in Strategic Renewal. Academy of Management Review 25 154-177

Ghoshal, S., H. Korine, G. Szulanski. 1994. Interunit Communication in Multinational Corporations. Management Science $\mathbf{4 0}$ 96-110

Gibson, C.B., J. Birkinshaw. 2004. The Antecedents, Consequences, and Mediating Role of Organizational Ambidexterity. Academy of Management Journal 47 209-226 
Gooding, R., J. Wagner. 1985. A Meta-analytic Review of the Relationship between Size and Performance: The Productivity and Efficiency of Organizations and their Subunits. Administrative Science Quarterly 30 462-481

Gopalakrishnan, S., F. Damanpour. 1994. Patterns of generation and adoption of innovation in organizations: Contingency models of innovation attributes. Journal of Engineering and Technology Management 11 95-116

Hage, J., M. Aiken. 1967. Program Change and Organizational Properties: A Comparative Analysis. American Journal of Sociology 72 503-519

Hambrick, D.C. 1983. Some Tests of the Effectiveness and Functional Attributes of Miles and Snow's Strategic Types. Academy of Management Journal 26 5-26

Han, J.K., H. Kim, R.K. Srivastava. 1998. Market Orientation and Organizational Performance: Is Innovation a Missing Link? Journal of Marketing 62 3-45

Hansen, G.S., B. Wernerfelt. 1989. Determinants of Firm Performance: The Relative Importance of Economic and Organizational Factors. Strategic Management Journal 10 399-411

Hansen, M.T. 1999. The Search-Transfer Problem: The Role of Weak Ties in Sharing Knowledge across Organization Subunits. Administrative Science Quarterly 44 82-111

Hansen, M.T. 2002. Knowledge Networks: Explaining Effective Knowledge Sharing in Multiunit Companies. Organization Science 13: 232-248

He, Z., P. Wong. 2004. Exploration and Exploitation: an Empirical Test of the Ambidexterity. Hypothesis. Organization Science 15 481-4

Hill, C.W.L., F.T. Rothaermel. 2003. The Performance of Incumbent Firms in the Face of Radical Technological Innovation. Academy of Management Review 28 257-274

James, L.R., R.G. Demaree, G. Wolf. 1993. R $\mathrm{wg}_{\mathrm{g}}$ : An Assessment of Within-Group Interrater Agreement. Journal of Applied Psychology 78 306-309

Jansen, J.J.P., F.A.J. van den Bosch, H.W. Volberda. 2005. Managing Potential and Realized Absorptive Capacity: How do Organizational Antecedents Matter? Academy of Management Journal 48 999-1015 
Jaworski, B.J., A.K. Kohli. 1993. Market Orientation: Antecedents and Consequences. Journal of Marketing 57 53-70

Jones, A.P., L.A. Johnson, M.C. Butler, D.S. Main. 1983. Apples and Oranges: An Empirical Comparison of Commonly Used Indices of Interrater Agreement. Academy of Management Journal $26507-519$

Khandwalla, P.N. 1977. Design of Organizations. New York: Harcourt Brace Jovanovich

Kirkman, B.L., B. Rosen. 1999. Beyond Self-management: Antecedents and Consequences of Team Empowerment. Academy of Management Journal 42 58-74

Kotha, S., A. Nair. 1995. Strategy and Environment as Determinants of Performance: Evidence from the Japanese Machine Tool Industry. Strategic Management Journal 16 497-518

Lee, J., J. Lee, H. Lee. 2003. Exploration and Exploitation in the Presence of Network Externalities. Management Science 49 553-570

Leonard-Barton, D. 1992. Core Capabilities and Core Rigidities: A Paradox in Managing New Product Development. Strategic Management Journal 13 111-125

Levinthal, D.A., J.G. March. 1993. The Myopia of Learning. Strategic Management Journal 14 95-112 Lewin, A.Y., C.P. Long, T.N. Caroll. 1999. The Coevolution of New Organizational Forms.

Organization Science 10 535-550

Lin, X., R. Germain. 2003. Organizational Structure, Context, Customer Orientation, and Performance: Lessons from Chinese State-owned Enterprises. Strategic Management Journal 24 1131-1151

Lumpkin, G. T., G.G. Dess. 2001. Linking Two Dimensions of Entrepreneurial Orientation to Firm Performance: The Moderating Role of Environment and Industry Life Cycle. Journal of Business Venturing 16 429-451

Lyles, M.A., C.R. Schwenk. 1992. Top Management, Strategy, and Organizational Knowledge Structures. Journal of International Business Studies. 29 155-174

March, J.G. 1991. Exploration and Exploitation in Organizational Learning Organization Science 2 7187

March, J.G., H.A. Simon. 1958. Organizations. John Wiley, New York 
Matusik, S.F., C.W.L. Hill. 1998. The Utilization of Contingent Work, Knowledge Creation, and Competitive Advantage. Academy of Management Review 23 680-697

McFadyen, M.A., A.A. Cannella. 2004. Social capital and knowledge creation: Diminishing returns of the number and strength of exchange relationships. Academy of Management Journal 47 735-746.

McGrath, R.G. 2001. Exploratory Learning, Innovative Capacity, and Managerial Oversight. Academy of Management Journal 44 118-131

Miller, D. 1987. The Structural and Environmental Correlates of Business Strategy. Strategic Management Journal 8 55-76

Miller, D., C. Droge. 1986. Psychological and Traditional Dimensions of Structure. Administrative Science Quarterly 31 539-560

Miller, D., P.H. Friesen. 1983. Strategy-Making and Environment: The Third Link. Strategic Management Journal 4 221-235

Moorman, C., A.S. Miner. 1997. The Impact of Organizational Memory on New Product Performance and Creativity. Journal of Marketing Research 34 91-106

Nahapiet, J., S. Ghoshal. 1998. Social Capital, Intellectual Capital, and the Organizational Advantage. Academy of Management Review 23 242-266

Neter, J., W. Wasserman, M.H. Kutner. 1990. Applied Linear Statistical Models. Homewood, IL: Irwin

Nobel, R., J. Birkinshaw. 1998. Innovation in Multinational Corporations: Control and Communication Patterns in International R\&D Operations. Strategic Management Journal 19 479-496

Pennings, J.M., F. Harianto. 1992. The Diffusion of Technological Innovation in the Commercial Banking Industry. Strategic Management Journal 13 29-46

Pierce, J.L., A.L. Delbecq. 1977. Organization Structure, Individual Attitudes and Innovation. Academy of Management Review 2 27-37

Rothaermel, R.T., D.L. Deeds. 2004. Exploration and Exploitation Alliances in Biotechnology: A System of new Product Development. Strategic Management Journal 25 201-221

Rowley, T., D. Behrens, D. Krackhardt. 2000. Redundant Governance Structures: An Analysis of Structural and Relational Embeddedness in the Steel and Semiconductor Industries. Strategic Management Journal 21 369-386 
Sethi, R., D.C. Smith, C.W. Park. 2001. Cross-Functional Product Development Teams, Creativity, and the Innovativeness of New Consumer Products. Journal of Marketing Research 38 73-85

Shane, S., S. Venkatraman. 2000. The Promise of Entrepreneurship as a Field of Research. Academy of Management Review 25 217-226

Sheremata, W.A. 2000. Centrifugal and Centripetal Forces in Radical New Product Development under Time Pressure. Academy of Management Review 25 389-408

Snow, C.C., L.G. Hrebiniak. 1980. Strategy, Distinctive Competence, and Organizational Performance. Administrative Science Quarterly 25 317-335

Sorensen, J.B., T.E. Stuart. 2000. Aging, Obsolescence and Organizational Innovation. Administrative Science Quarterly 45 81-113

Subramaniam, M., M.A. Youndt. 2005. The Influence of Intellectual Capital on the Types of Innovative Capabilities. Academy of Management Journal 48 450-463

Tsai, W. 2001. Knowledge Transfer in Intra-organizational Networks: Effects of Network Position and Absorptive Capacity on Business Unit Innovation and Performance. Academy of Management Journal 44 996-1004

Tsai, W. 2002. Social Structure of 'Coopetition' Within a Multiunit Organization: Coordination, Competition, and Intraorganizational Knowledge Sharing. Organization Science 13 179-190

Tsai, W., S. Ghoshal. 1998. Social capital and value creation: The role of intrafirm networks. Academy of Management Journal 41 464-476

Tushman, M.L. and C.A. O’Reilly. 1996. Ambidextrous Organizations: Managing Evolutionary and Revolutionary Change. California Management Review 38 8-29

Uzzi, B. 1997. Social Structure and Competition in Interfirm Networks: The Paradox of Embeddedness. Administrative Science Quarterly 42 35-67

Uzzi, B., R. Lancaster. 2003. Relational embeddedness and Learning: The Case of Bank Loan Managers and Their Clients. Management Science 49 383-399

Van de Ven, A.H. 1986. Central Problems in Management of Innovation. Management Science 32 590607 
Vera, D., M. Crossan. 2004. Strategic Leadership and Organization Learning, Academy of Management Review 29 222-240

Volberda, H.W., G.H. Van Bruggen. 1997. Environmental Turbulence: A Look into its Dimensionality. NOBO Onderzoeksdag 1997, Enschede

Walker, G., B. Kogut, W. Shan. 1997. Social Capital, Structural Holes, and the Formation of an Industry Network. Organization Science 8 109-125

Weick, K.E. 1979. The Social Psychology of Organizing. Reading, MA: Addison-Wesley, Zaltman, G., R. Duncan, J. Holbek. 1973. Innovations and Organizations. New York: Wiley

Zahra, S.A. 1996. Technology Strategy and Financial Performance: Examining the Moderating Role of the Firm's Competitive Environment. Journal of Business Venturing 11 189-219

Zahra, S.A., W.C. Bogner. 1999. Technology Strategy and Software new Venture's Performance: Exploring Effect of the Competitive Environment. Journal of Business Venturing 15 135-173

Zander, U., B. Kogut. 1995. Knowledge and the Speed of the Transfer and Imitation of Organizational Capabilities: An Empirical Test. Organization Science 6 76-92

Zmud, R.W. 1982. Diffusion of Modern Software Practices: Influence of centralization and formalization. Management Science 28 1421-1431

Zollo, M.M., S.G. Winter. 2002. Deliberate Learning and the Evolution of Dynamic Capabilities. Organization Science 13 339-351 
TABLE 1

Means, Standard Deviations, and Correlations ${ }^{\mathrm{a}}$

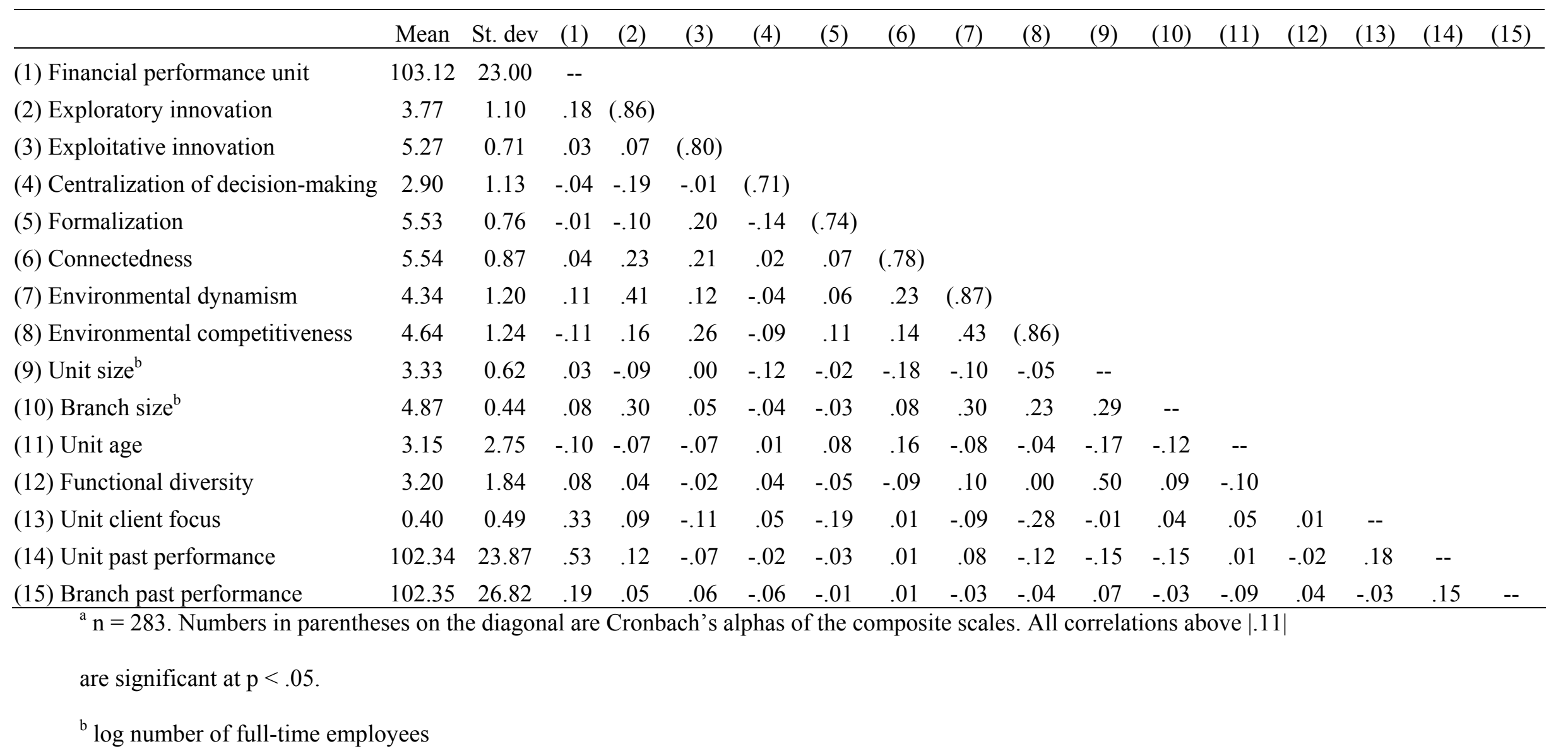


TABLE 2

Results of Hierarchical Regression Analyses: Effects on

Exploratory Innovation, Exploitative Innovation, and Financial Performance ${ }^{a}$

\begin{tabular}{|c|c|c|c|c|c|c|c|}
\hline & & \multicolumn{2}{|c|}{ Exploratory innovation } & \multicolumn{2}{|c|}{ Exploitative Innovation } & \multicolumn{2}{|c|}{ Financial Performance } \\
\hline & & Model 1 & Model 2 & Model 3 & Model 4 & Model 5 & Model 6 \\
\hline Unit size & & $-0.26^{* * *}$ & $-0.24 * * *$ & -0.02 & 0.03 & 0.04 & 0.04 \\
\hline Branch size & & $0.39 * * *$ & $0.35 * * *$ & 0.05 & 0.02 & 0.11 & 0.08 \\
\hline Unit age & & -0.04 & -0.09 & -0.06 & -0.10 & -0.08 & -0.05 \\
\hline Functional diversity & & $0.14 *$ & $0.15^{*}$ & -0.03 & -0.03 & 0.05 & 0.02 \\
\hline Unit client focus & & 0.06 & 0.03 & -0.10 & -0.06 & $0.24 * * *$ & $0.27 * * *$ \\
\hline Unit past performance & & $0.15^{*}$ & $0.13 *$ & -0.05 & -0.05 & $0.49 * * *$ & $0.49 * * *$ \\
\hline Branch past performance & & 0.06 & 0.05 & 0.07 & 0.06 & $0.10 *$ & $0.10^{*}$ \\
\hline Environmental dynamism & & & & & & 0.04 & $0.12 *$ \\
\hline Environmental competitiveness & & & & & & -0.05 & -0.09 \\
\hline Exploratory innovation & & & & & & 0.02 & 0.02 \\
\hline Exploitative innovation & & & & & & 0.09 & 0.03 \\
\hline \multicolumn{8}{|l|}{ Organizational Antecedents } \\
\hline Centralization of decision-making & $\mathrm{H} 1 \mathrm{a} / \mathrm{b}$ & & $-0.17 * *$ & & 0.04 & & \\
\hline Formalization & $\mathrm{H} 2 \mathrm{a} / \mathrm{b}$ & & -0.07 & & $0.18 * *$ & & \\
\hline Connectedness & $\mathrm{H} 3 \mathrm{a} / \mathrm{b}$ & & $0.20 * *$ & & $0.21 * *$ & & \\
\hline Connectedness squared & & & -0.08 & & & & \\
\hline \multicolumn{8}{|l|}{ Interaction Effects } \\
\hline Exploratory innovation*Environmental dynamism & $\mathrm{H} 4 \mathrm{a}$ & & & & & & $0.15 * *$ \\
\hline Exploitative innovation*Environmental dynamism & $\mathrm{H} 4 \mathrm{~b}$ & & & & & & $-0.23 * * *$ \\
\hline Exploratory innovation*Environmental competitiveness & $\mathrm{H} 5 \mathrm{a}$ & & & & & & -0.05 \\
\hline Exploitative innovation*Environmental competitiveness & $\mathrm{H} 5 \mathrm{~b}$ & & & & & & $0.19 * * *$ \\
\hline $\mathrm{R}^{2}$ & & $.16 * * *$ & $.26 * * *$ & .03 & $.10 * *$ & $.39 * * *$ & $.47 * * *$ \\
\hline$\Delta \mathrm{R}^{2}$ & & & $.10 * * *$ & & $.07 * * *$ & & $.08 * * *$ \\
\hline
\end{tabular}

$* \mathrm{p}<.05, * * \mathrm{p}<.01, * * * \mathrm{p}<.001$ 
FIGURE 1

THE MODERATING EFFECT OF ENVIRONMENTAL DYNAMISM

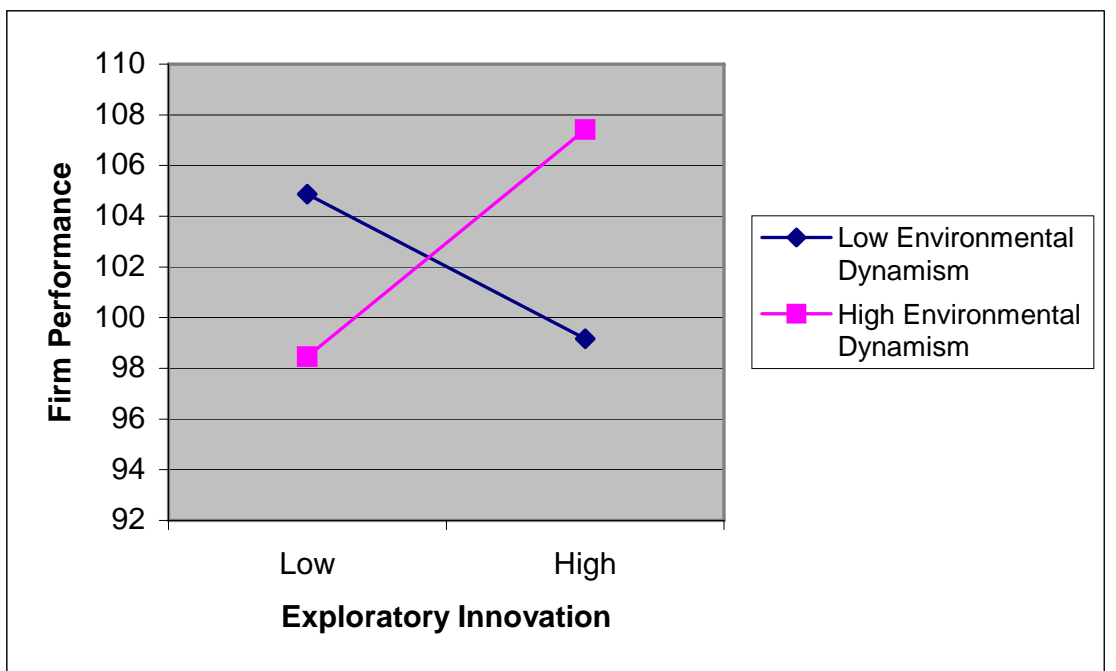

FIGURE 2

THE MODERATING EFFECT OF ENVIRONMENTAL DYNAMISM

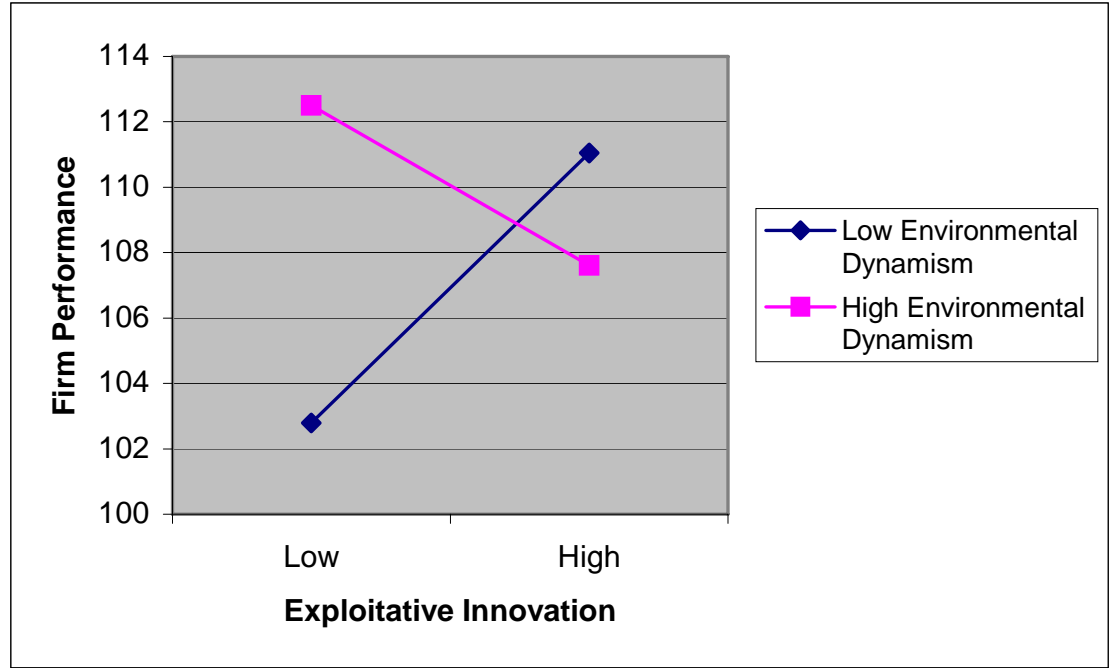

FIGURE 3

The Moderating EfFEct of ENVIRONMENTAL CoMPETITIVENESS

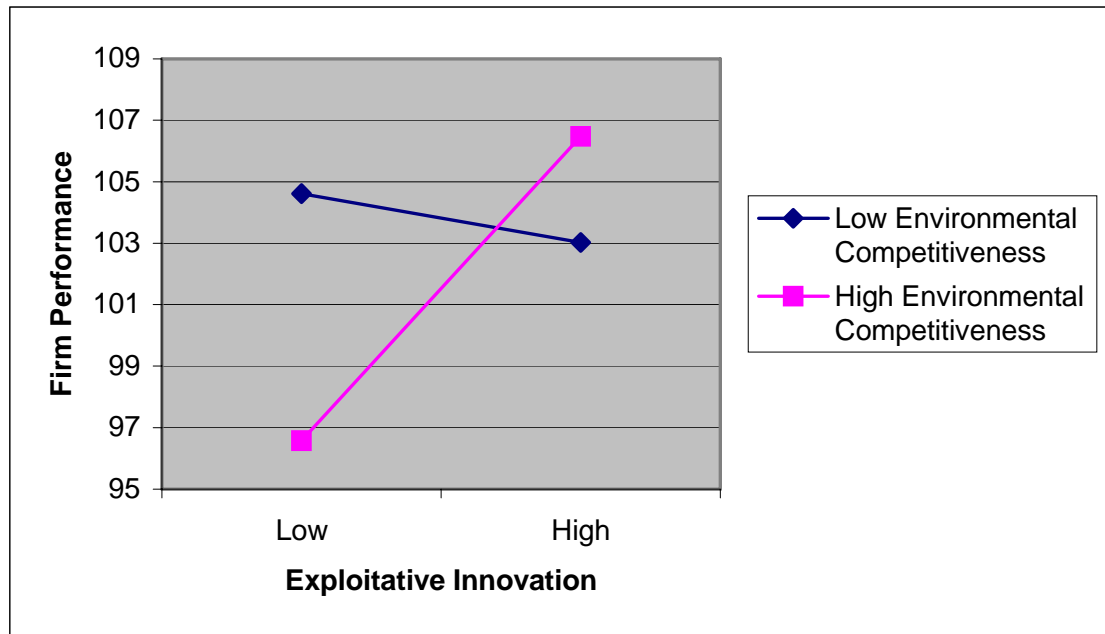


Appendix Measures and Items at Organizational Unit Level ${ }^{\mathrm{a}}$

\section{Exploratory innovation}

Our unit accepts demands that go beyond existing products and services

We invent new products and services

We experiment with new products and services in our local market

We commercialize products and services that are completely new to our unit

We frequently utilize new opportunities in new markets

Our unit regularly uses new distribution channels

We regularly search for and approach new clients in new markets ${ }^{\mathrm{b}}$

\section{Exploitative innovation}

We frequently refine the provision of existing products and services

We regularly implement small adaptations to existing products and services

We introduce improved, but existing products and services for our local market

We improve our provision's efficiency of products and services

We increase economies of scales in existing markets

Our unit expands services for existing clients

Lowering costs of internal processes is an important objective ${ }^{b}$

\section{Centralization of decision-making (Hage and Aiken 1967, Dewar et al. 1980)}

There can be little action taken here until a supervisor approves a decision

A person who wants to make his own decisions would be quickly discouraged

Even small matters have to be referred to someone higher up for a final decision

Unit members need to ask their supervisor before they do almost anything

Most decisions people make here have to have their supervisor's approval

\section{Formalization (Desphandé and Zaltman 1982)}

Whatever situation arises, written procedures are available for dealing with it

Rules and procedures occupy a central place in the organizational unit

Written records are kept of everyone's performance

Employees in our organizational unit are hardly checked for rule violations ${ }^{\circledR}$

Written job-descriptions are formulated for positions at all levels in the organizational unit

\section{Connectedness (Jaworski and Kohli 1993)}

In our organizational unit, there is ample opportunity for informal 'hall talk' among employees

In this unit, employees from different departments feel comfortable calling each other when the need arises

Managers discourage employees discussing work related matters with those who are not immediate superiors $\mathbb{R}$

People around here are quite accessible to each other

In this organizational unit, it is easy to talk with virtually anyone you need to, regardless of rank or position

\section{Environmental dynamism (Dill 1958, Volberda and Van Bruggen 1997)}

Environmental changes in our local market are intense

Our clients regularly ask for new products and services

In our local market, changes are taking place continuously

In a year, nothing has changed in our market $(\mathbb{R}$

In our market, the volumes of products and services to be delivered change fast and often

\section{Environmental competitiveness (Birkinshaw et al. 1998, Jaworski and Kohli 1993)}

Competition in our local market is intense

Our organizational unit has relatively strong competitors

Competition in our local market is extremely high

Price competition is a hallmark of our local market

${ }^{\mathrm{a}}$ All items were measured on a seven-point scale, anchored by $1=$ strongly disagree and $7=$ strongly agree; ${ }^{\mathrm{b}}$ Item deleted after exploratory factor analysis; ${ }^{\circledR}$ reversed item 


\section{Publications in the Report Series Research ${ }^{*}$ in Management}

\section{ERIM Research Program: "Strategy and Entrepreneurship"}

2006

Modeling Brand Extension as a Real Option: How Expectation, Competition and Financial Constraints Drive the Timing of Extensions

Lenny H. Pattikawa

ERS-2006-030-STR

http://hdl.handle.net/1765/7855

Coping with Problems of Understanding in Interorganizational Relationships: Using Formalization as a Means to make Sense Paul W.L. Vlaar, Frans A.J. Van den Bosch and Henk W. Volberda

ERS-2006-034-STR

http://hdl.handle.net/1765/7879

On the Evolution of Trust, Distrust, and Formal Coordination and Control in Interorganizational Relationships: Towards an Integrative Framework

Paul W.L. Vlaar, Frans A.J. Van den Bosch and Henk W. Volberda

ERS-2006-035-STR

http://hdl.handle.net/1765/7877

Complex Incremental Product Innovation in Established Service Firms: A Micro Institutional Perspective

Patrick A.M. Vermeulen, Frans A.J. Van den Bosch and Henk W. Volberda

ERS-2006-037-STR

$\underline{\text { http://hdl.handle.net/1765/7880 }}$

Exploratory Innovation, Exploitative Innovation, and Performance: Effects of Organizational Antecedents and Environmental Moderators

Justin J.P. Jansen, Frans A.J. Van den Bosch and Henk W. Volberda

ERS-2006-038-STR

\footnotetext{
A complete overview of the ERIM Report Series Research in Management: https://ep.eur.nl/handle/1765/1

ERIM Research Programs:

LIS Business Processes, Logistics and Information Systems

ORG Organizing for Performance

MKT Marketing

F\&A Finance and Accounting

STR Strategy and Entrepreneurship
} 